\title{
Voces femeninas en Chile: miradas sobre el ser mosaico*
}

\author{
Female voices in Chile: views on being Hebrew
}

\author{
Rodrigo Cánovas Emhart ${ }^{1}$, Jorge Scherman Filer ${ }^{2}$ \\ ${ }^{1}$ Pontificia Universidad Católica de Chile, Facultad de Letras, Santiago de Chile, Chile, \\ e-mail: rcanovas@puc.cl \\ ${ }^{2}$ Estudiante de Doctorado en Literatura, Pontificia Universidad Católica de Chile, \\ Santiago de Chile, Chile, \\ e-mail: scherman@terra.cl
}

En este trabajo se analizan los textos de cuatro escritoras chilenas de ascendencia judía en las que se observan miradas muy diversas sobre qué significa el ser judío: Para siempre en mi memoria, de Sonia Guralnik; Sagrada memoria: Reminiscencias de una niña judía en Chile y Always from Somewhere Else: A Memoir of my Jewish Chilean Father, de Marjorie Agosín; Poste Restante, de Cynthia Rimsky; y Escenario de guerra, de Andrea Jeftanovic. Estos libros han sido escritos desde los espacios del gueto, el árbol genealógico y la errancia, el viaje circular entre los orígenes judíos y chilenos y la tragedia familiar y mundial asociada a los conflictos bélicos del siglo XX.

Palabras clave: memoria, árbol genealógico, identidad hebrea, judío errante, narrativa chilena.

In this paper we analyze the books of four female Chilean-Jewish writers, in which very different views on what it means to be Hebrew are observed: Para siempre en mi memoria (Sonia Guralnik); Sagrada memoria: Reminiscencias de una niña judía en Chile y Always from Somewhere Else: A Memoir of my Jewish Chilean Father (Marjorie Agosín); Poste Restante (Cynthia Rimsky); and Escenario de guerra (Andrea Jeftanovic). These texts have been written from the following spaces: the ghetto, the genealogical tree and the wandering Jew, the circular journey between Hebrew and Chilean origins and the family and world tragedies associated with the war conflicts of the twentieth century.

Key words: memory, genealogical tree, Hebrew identity, wandering Jew, Chilean narrative.

\footnotetext{
* Este trabajo forma parte del Proyecto Fondecyt 1051011.
} 


\section{INTRODUCCIÓN}

La gama de experiencias vitales de las escritoras chilenas de ascendencia judía es tan variada como su literatura. Observamos el caso de Sonia Guralnik, quien llegó desde Ucrania en los años 30 del siglo pasado y permaneció en Chile hasta su muerte en 2007; se trata de una inmigrante que se integró en su nuevo entorno y que se mantuvo apegada a su tradición mosaica. El de Marjorie Agosín, que vivió en el país hasta los trece años y se trasladó en 1968 con su familia a Estados Unidos, donde permanece hasta el día de hoy; se ve a sí misma como una judía-chilena, aunque no vive en un país que considera antisemita y pro alemán ${ }^{1}$. Y los casos de Cynthia Rimsky y Andrea Jeftanovic, las más jóvenes de las escritoras de la serie que analizaremos, quienes nacieron en la segunda mitad del siglo pasado y permanecen en Chile, cuyo ser hebreo está cruzado por el mestizaje cultural judío-chileno y el impacto de la globalización ${ }^{2}$. Se trata de tres generaciones de mujeres en las que la identidad israelita actúa como refugio y/o foco de tensión.

Las cuatro escritoras muestran en su literatura maneras muy distintas de aproximación a sus raíces hebreas. Guralnik en su novela Para siempre en mi memoria nos relata el largo camino que recorre su heroína (la señora Gitl) desde un pequeño gueto judío (una pensión en el barrio Independencia), hasta que ya mayor se integra en el país de acogida. Por su parte, Agosín recurre al árbol genealógico, escribiendo en Sagrada memoria y Always... las memorias de Frida (su madre), y Moisés (su padre), una historia de judíos errantes hasta llegar a Chile en las primeras décadas del siglo XX, para volver a ser expulsados por el prejuicio antisemita que caracterizaría a nuestra sociedad. Cynthia y Tamara, en cambio, las protagonistas de los textos Poste Restante y Escenario de guerra, de Rimsky y Jeftanovic, respectivamente, realizan un viaje circular de ida y vuelta a los orígenes, un periplo de búsqueda identitaria que sólo se zanja a través de la escritura como último lugar de amparo.

En este trabajo se realiza un análisis de los libros de estas escritoras, para terminar con un breve ejercicio de literatura comparada donde se señalan similitudes y diferencias en las miradas sobre el ser judaico.

\section{El COBIJO de la IDENTIDAd JUdía. MarJorie Agosín}

Entre las escritoras y escritores chilenos de ascendencia judía, Marjorie Agosín es una voz destacada ${ }^{3}$. En su labor con la palabra escribió las memorias de su madre (Frida) y de su padre (Moisés). En Sagrada memoria: Reminiscencias de una niña judía en Chile (1994), Agosín asume la voz de Frida y nos cuenta su historia. El

\footnotetext{
${ }^{1}$ Para una reflexión sobre la génesis de los relatos de Guralnik y Agosín en el ámbito de la diáspora contemporánea y sobre los paradigmas migratorios de los personajes tanto masculinos como femeninos de sus obras, consúltese en el ensayo de Elizabeth R. Horan.

2 Un adecuado marco de lectura para los descalces generacionales del ser mosaico en América Latina es presentado por Gilda Waldman desde el comentario de Poste Restante.

${ }^{3}$ Marjorie Agosín es escritora (poeta, narradora y ensayista). Habiendo vivido sus primeros trece años en Chile, viaja con sus padres en 1968 hacia Estados Unidos, donde la familia fija su residencia. Activista de Derechos Humanos y difusora de los trabajos de las mujeres judías latinoamericanas, se desempeña como académica en Wellesley College, Boston.
} 
libro tiene una versión posterior en inglés denominado A Cross and a Star: Memoirs of a Jewish Girl in Chile (1997). Tiempo después publicó en inglés Always from Somewhere Else: A Memoir of my Jewish Father (1998), donde la autora nos narra las memorias de Moisés.

Ambos libros nos revelan que Marjorie Agosín pertenece a un grupo familiar de seres errantes, que cruzan fronteras, aprenden nuevas lenguas y huyen de las persecuciones, pero permanecen siempre aferrados a su identidad judía. Los países donde han habitado las generaciones Agosín más recientes, específicamente Chile y EEUU, han sido para su gente una mezcla del cielo y el infierno, espacios ambiguos entre la integración y el clan familiar. No se sienten del todo cómodos en Chile, y también desencontrados en EEUU, porque en esas tierras, además de judíos, son latinoamericanos. Y han desechado Israel como alternativa, donde los ven como sefardíes porque hablan castellano. Confirmando este sino apátrida, la autora dice: "We are Jews without a country" (Agosín 1998: 211).

A pesar de sus diferencias estéticas, de contenido, espacios y tiempo cubiertos por la narración, Always... es un complemento indispensable de Sagrada memoria para intentar entender más cabalmente el mundo de esta familia de judíos errantes.

\subsection{VOCES MOSAICAS}

La autora nos aclara que ambos textos fueron construidos a partir de conversaciones con sus progenitores; hasta la fecha, Always... no ha sido editado en español, idioma en que Marjorie Agosín ha escrito ambas obras. Y resulta misterioso que habiendo sido ambas escritas en español, sólo una se haya publicado en traducción inglesa (no hecha por la autora), generándose así una bifurcación en la recepción de estas memorias familiares: dos públicos, dos sensibilidades.

En Sagrada memoria, Agosín asume la voz de Frida y se atiene sobre todo a la historia materna, recreando su visión de mundo y su sensibilidad hasta el término de su adolescencia, cuando se casa con Moisés. En el caso de Sagrada memoria, Frida "ofuscada" (Agosín 1994: 15) le insinuó a su hija escritora que relatara parte de su vida: "Por mucho tiempo, oí a mi madre contarme las hazañas de una infancia sumida en la tristeza de las extranjerías, y recogí sus palabras. No inventé nada, pero tal vez todo. A veces su voz se enrolla con la mía para confundirse con el lenguaje del amor" (Agosín 1994: 16).

Acaso lo más perturbador y original de Sagrada memoria sea su voz poética, híbrida y fragmentaria. Aquí habla la hija en el lugar de la madre (ella dice "Yo, Frida", sin dejar de ser Marjorie), repitiendo el gesto milenario de hacerse cargo de una tradición. Es, por lo demás, una estrategia de sobrevivencia de una comunidad que vive constantemente la amenaza del cercenamiento de sus ramas. Sagrada memoria es un texto compuesto por viñetas de gran ritmo lírico, donde Marjorie Agosín ensaya una poética de las cosas que le permite ejercer una sublimación del mundo maligno, una conversión del mal en una armonía plástica.

Always... es muy distinto a este respecto. Si bien su padre también le relató su historia, quien habla todo el tiempo es la autora-narradora, ya sea para contar los avatares de Moisés (personales, familiares y laborales) o bien su propia vida junto a él. Son las memorias de su padre, pero al mismo tiempo los recuerdos de Marjorie Agosín, gatillados al parecer por la misma escritura del texto. 
Una paradoja de Always... es que se reitera que la reconstrucción de la historia familiar y su traspaso a Marjorie Agosín provendría básicamente de Moisés, a pesar de que se señala: "My father says that his parents never talk to him about the vicissitudes of life and the voyages they had made, even though his questions were endless" (Agosín 1998: 72).

¿Cómo interpretar en Always... lo que a todas luces es una construcción literaria en parte imaginada y recreada, pero presentada bajo el subtítulo de A Memoir...? A nuestro entender, sabiendo que la memoria es fragmentaria, y que además muchos judíos inmigrantes optaron por el silencio, lo que Agosín hace en ocasiones es contar un relato judío universal, incluyendo a su genealogía en él. Desde ahí entendemos que en las viñetas denominadas "Memory in her Carriage of Mist" y "My Father's Memory", la autora, respectivamente, nos diga: "In the book of my father's memory I have toyed with certain chapters and invented others" (Agosín 1998: 222); "I listen to him diligently, eagerly, and as I write I invent him; I rearrange certain stories, disassemble others, and sort out his life, which is, above else, mine as well" (Agosín 1998: 240-241). Marjorie Agosín tiene plena conciencia de que al narrar la historia de su padre quiere contar también, y viceversa, la saga de su pueblo milenario. La declaración de las intenciones de la autora es explícita. Escribe para salvar su propia vida, cual Sherezade, nos confiesa (Agosín 1998: 222); para decir las palabras que nadie debe olvidar (Agosín 1998: 223); porque las palabras la llevarán más cerca de la verdad (Agosín 1998: 224); porque sigue la tradición judía, el gran libro de la vida y la memoria, quizá el libro de Dios (Agosín 1998: 236); porque escribir es también una forma de legitimar historias (Agosín 1998: 241); porque al contar la historia de Moisés Agosín, narra la historia de los judíos chilenos, quienes le rezan a la Virgen del Carmen, y que tienen cruces y estrellas de David en sus casas (Agosín 1998: 241); y, por último, Always... es un regalo a su padre para celebrar su existencia (Agosín 1998: 242).

En síntesis, la autora habla por su propia genealogía (fundamentalmente femenina) en Sagrada memoria. Y escribe en Always... por ella misma y la rama paterna de su árbol, por los judíos chilenos, y por el pueblo hebreo en su conjunto.

\subsection{MEMORIA TRAUMATICA}

En Sagrada memoria la voz narrativa (eslabón de una cadena precaria) enuncia una cartografía diaspórica: los abuelos provienen de Odessa y Viena; la tía Liesl vivió en Praga antes de trasplantarse a Cochabamba; la señora Schpirman, acogida como refugiada en suelo chileno, nació en Jolem, una localidad judía de Polonia que no sale en los mapas, de la cual salió huyendo despavorida sin su dentadura.

La narración recrea básicamente la vida de la niña Frida en Osorno en los años previos y durante la II Guerra Mundial. Un espacio ominoso donde a la heroína y a su hermano Jaime los niños les cantaban: “[...] ¿quién se comió los panes del horno?, y el coro respondía: el perro judío, 'los perros judíos', y nos miraban con esa mirada plasmada de asombro y maldita inocencia” (Agosín 1994: 60).

En consecuencia, el trabajo de la memoria es el trabajo con la imagen traumática del Holocausto, de revivirlo en la pantalla del recuerdo para asumir la cultura desde ese estigma y de paso enrostrar a la Humanidad su insensatez. Desde el Holocausto, Osorno es su cifra adelantada en los años 30 (en sus letras los hornos encendidos), y 
un testimonio del porvenir: en los años 90, las fotos de Hitler siguen allí, ofrecidas ahora en las tiendas de antigüedades para adornar la casa familiar. Siniestramente, Osorno, "territorio de extranjeros, de nazis, de indígenas y de escasos judíos" (Agosín 1994: 57), se revela como un modelo reducido de la sociedad chilena, cuya impronta católica enfatiza el antisemitismo. Han pasado cincuenta años, y la evaluación de Frida de los alemanes y nazis es que poco le han aportado al país (aparte de sus casas lindas y aseadas, y sus embutidos), y "no han sabido apreciar la tolerancia del pueblo chileno" (Agosín 1994: 67).

La inserción de la gente de Chile y la religión católica aparece básicamente a través de las empleadas de la casa. La figura central es Carmen Carrasco, quien se salvó del terremoto de Chillán de 1939, mientras su niño murió en el sismo. Habrá de ser "la Carmencita" quien les enseñe el "Padre Nuestro" y bautice secretamente a Frida y Jaime. El cruce judío-católico aparece en una clave: Carmen llegando a Osorno desde Chillán, trayendo sal, azúcar y una vela, elementos que en la tradición judía se requieren para subsistir y fundar un hogar (lo mismo habrá de hacer Raquel, la madre de Moisés).

Dentro de este contexto, Sagrada memoria, como si fuese un conjuro, recrea el humor judío. Los recuerdos de Frida de su infancia, los recuerdos que engendraron a la hija están teñidos de situaciones humorísticamente escabrosas, como aquel maniquí de la vitrina del tío Isaak que tiene un solo pie; la sonrisa brillante de la señora Schpirman bajándose del tren con una inmensa dentadura de oro; o los juegos sexuales dentro de los catafalcos con los amiguitos de la infancia cuyos padres eran dueños de una funeraria. Y relacionado con la religión católica, en especial la Pascua, Jesús y la Virgen María (la preferida de Frida, por sus ojos azules como ella), aparecen en el texto los pocos arrestos de humor irónico: "Por eso dicen que los judíos somos malos, porque nos comimos el cuerpo de Cristo con sus ojitos azules, así, completito" (Agosín 1994: 42); "Sin embargo, me gusta la Pascua: ver a un gordo sudando en medio del verano chileno mientras yo me como un durazno" (Agosín 1994: 48). Esta última broma, que parece inocente, no es menor, pues cierra una viñeta, "Pascuas", donde se relata que Joseph (abuelo materno de la autora) decía que la Pascua es la noche negra de los judíos, y donde Frida manifiesta su deseos de ser cristiana durante el día, lo que se contrapone con noches de "abuelas calcinadas, de alambres de púas y de gritos" (Agosín 1994: 48). Y respecto de lo goys -gentiles o no judíos-, está otra enseñanza de Joseph: no es bueno juntarse con ellos; Frida anota que no se trata de prejuicios, "[...] sino por un viejo temor del paranoico, del perseguido, del sobreviviente" (Agosín 1994: 40). Frida habrá de tener como amiguitas, en consecuencia, a las pocas judías de su entorno.

Sagrada memoria se cierra con el capítulo "Mi esposo", una sección que constituye un epílogo y una apertura hacia Always... (se repiten episodios), donde Frida ya en la capital nos cuenta del encuentro y del amor con Moisés Agosín desde sus quince años, sellado por un matrimonio lleno de simbolismo: "Me casé el diecinueve de junio de 1948, año en que Israel dejó de llamarse Palestina y se convirtió en un estado libre e independiente" (Agosín 1994: 111).

\subsection{ANTISEMITISMO Y ERRANCIA}

Always... comienza con la historia prechilena de Raquel y Abraham (los abuelos paternos de la autora). Se trata de un relato de errancia tópica judía: pobres de 
Europa de Este, que huyen de la discriminación, los progroms y las guerras en Rusia y luego del descalabro de los Balcanes en las primeras décadas del siglo XX; con una emigración en 1926 desde Marsella hacia Chile. Así, la familia Agosín es presentada como un emblema del Judío Errante, adquiriendo un rasgo de excepcionalidad. Y ya instalados en Quillota (la única familia judía), Abraham trabaja de sastre, es respetuoso y cauto con sus clientes, y establece alianzas con árabes, aprovechando que sabe turco. Pero los idiomas ancestrales y aprendidos quedan sumergidos. Será Raquel quien los hará aflorar, cantando en ruso, turco y francés frente a la comunidad quillotana. El judaísmo se vivirá como un asunto básicamente privado, sin pares ni sinagogas, alejados de lo religioso. En la más alegórica escena de identidad e integración, una víspera de Pascua, a Abraham se le solicita que decore Quillota con estrellas. Pues bien, en vez de la estrella chilena de cinco puntas, Abraham las reemplaza por el maguen David, la estrella de seis puntas: "The city was Jewish for the night and no one knew it" (Agosín 1998: 93).

Pero, por sobre todo, Always... son las memorias de un héroe (Moisés) construido de manera ejemplar, en el cual Chile es un modelo reducido del mundo, donde son legibles la Inquisición (católica) y el Holocausto (nazi), no habiendo buenas noticias de la Tierra Prometida (EEUU e Israel, concebidos como estaciones de espera, incómodas y engañosas para el hablante nativo de lengua española). Y con todo, se vuelve siempre al país del fin del mundo, pues es lo irrenunciable, y lo que mantiene la utopía de los orígenes.

Estas memorias polemizan con discursos culturales ya instalados en la colectividad chilena: la alabanza de la aldea (el tranquilo pueblo frutal de Quillota, donde por lo demás el padre de Moisés es declarado Hijo Ilustre), los ideales libertarios de la Universidad de Chile (la Casa de Bello, espacio de deslegitimación), y la misma tradición democrática (la dictadura sería un estado natural descarnado de una sociedad prejuiciosa: "[...] a desperate and servile Chile, overflowing with racial hostility", Agosín 1998: 148).

No obstante, el hito clave que llevó a Moisés y su familia a abandonar Chile en 1968 fue la acusación a Moisés de venderse a los yanquis, por recibir financiamiento desde fundaciones estadounidenses para sus investigaciones. Desde todo espectro político lo rechazaban, y fue amenazado de muerte. Este episodio, además, lo expuso junto a los nombres de los suyos a toda la prensa de Santiago. Amigos le recomendaron afiliarse al Partido Comunista para salvar su laboratorio, pero Moisés Agosín optó por "to keep his political autonomy instead and chose exile -or, I should say, exile chose him" (Agosín 1998: 170).

Entendemos del texto que esta situación se deriva del antisemitismo y del ambiente político en Chile a fines de los 60: "[...] he knew that there would be no place, amid de battles of the left and right, for a lover of laboratories and of Bach, for an independent thinker, for a Jew" (Agosín 1998: 169). Esta situación se mantendría hasta fines de los 90: "Today, under a democracy, Chile continues to be governed as if were a small feudal kingdom, run by people with the same surnames and wealth" (Agosín 1998: 140); "The Jews of Chile still live in an atmosphere of isolation and distrust, while German presence remains strong" (Agosín 1998: 227).

La historia de Moisés en Always... es la de quien debe partir, expulsado por la mediocridad de un entorno prejuicioso, que se mantiene inalterable en el tiempo: "In Chile, anti-Semitism remained resilient through periods of cultural change and 
political upheaval; it endured" (Agosín 1998: 169). Judío errante, se constituye desde los márgenes de la censura católica (en Chile), la cultura anglosajona (el pragmatismo comercial y el prejuicio contra el ser latino en EEUU), y también desde las propias censuras dentro de la comunidad judaica: "For the Israelis, we are Sephardim because we speak Spanish. It is interesting how even the land of Israel transfigures our identity" (Agosín 1998: 204).

Así como en el texto sobre Frida la Historia se presenta como un conjunto de versiones sobre el Holocausto, en el caso del padre, su biografía y la sociedad chilena también se constituyen desde el eje continuo de las repeticiones en torno a un prejuicio resiliente. El Chile pro germano de fines de los años 30 se corresponde con el Chile fascista de 1973, y la tortura de judíos en la dictadura argentina se realiza ante una audiencia complaciente, tal como en los Autos de Fe de la Inquisición. La Historia gira en redondo, expulsando a los judíos, no importando tiempo ni lugar.

A modo de colofón, indiquemos que esta visión teológica de la existencia -que tiende a los universales, como la filosofía y la literatura, y no a los particulares, como la historia, en términos de Aristóteles- obliga a ciertos ajustes en el manejo de la información biográfica y de la argumentación en torno a la expulsión sufrida desde los países de acogida. Así, Moisés y su familia nuclear emigran de Chile en 1968, nos dice la autora, y al mismo tiempo se señala que el padre se adelanta a los hechos que iban a ocurrir (golpe de Estado de 1973 y prolongada dictadura) partiendo antes. Y acaso por ello, también se indica (ambiguamente, en un par de ocasiones) que se exilió debido a los sucesos de 1973.

Marjorie Agosín presenta en Sagrada memoria, y sobre todo en Always..., una escritura afirmada en principios y una visión de mundo bipolar: ellos (el genérico "they" con que nos encontramos desde la segunda y undécima líneas de Always... (Agosín 1998: 51)), y nosotros. Los goys y los judíos, ambos espacios homogéneos y confrontados. En Always... se privilegian las generalizaciones, dejando en segundo plano la diversidad característica de la sociedad finisecular.

\section{La PENSión de la SEÑora Gitl Sonia GuRalnik}

Avecindada en Chile desde la década de los 30, proveniente de Ucrania, Sonia Guralnik formó parte de la primera generación de judíos europeo-orientales que se trasladaron al país desde inicios del siglo pasado. Fue la escritora pionera de ascendencia judía; ya con sesenta años, publicó en Chile ${ }^{4}$.

Su novela Para siempre en mi memoria está poblada por seres desolados y tristes, judíos de la diáspora, que aparecen ante nuestros ojos como adultos-niños. Habitan en la pensión de la protagonista, la señora Gitl, en el Santiago de las décadas de los 30 y 40. La residencial del barrio Independencia y sus huéspedes nada tienen que ver con la realidad actual de la comunidad hebrea. Casi todos estos inmigrantes llegan y viven, con su pobreza y con la inocencia pegada a sus espaldas. Para siempre en mi

\footnotetext{
${ }^{4}$ Nació en Rusia (¿1923-1925?), y vivió en Ucrania antes de su emigración a Chile; falleció en Santiago (2007). Participó en talleres literarios y publicó cuentos en El samovar (1983); Relatos en sepia (1987) y Recuento de la mujer gusano (1991). Además, sus relatos breves fueron incluidos en antologías como Salidas de madre (Planeta, 1997) y What is Secret (White Pine Press, 1995).
} 
memoria es una novela mosaico que rescata la experiencia de las "vidas mínimas" de estos expatriados judíos en nuestra capital ${ }^{5}$.

La pensión opera como una cavidad virtual, un cuerpo enquistado en un barrio chileno que lo soporta sin grandes prejuicios, el cual contiene, a su vez, a otros judíos, de mayor poder adquisitivo. Uno tiene la impresión de que la residencial judía es un espacio de protección mínimo abierto en cualquier parte del mapa, en cuyo interior los doce pensionistas (como las doce tribus) se empeñan en vivir ciertos ritos básicos y la permanencia de la tradición (con Gitl como bastión y agente de transformación). Sin la dueña de la pensión, este gueto está destinado a morir, pues en la residencial sus habitantes son cuerpos senescentes suspendidos en el aire, lo que se refuerza en el contraste con los judíos del entorno barrial que se han abierto a la comunidad nacional.

Gitl y Samuel recorren un camino de dos décadas en Santiago hasta sentirse integrados en el país, cuando el marido compra un boliche en La Vega para trabajar junto a su esposa; será ella quien le pondrá nombre: "El fin del mundo". Justo lo contrario, porque desde ese momento la historia y la vida entera entrarán en la pensión, en un nuevo Génesis, en Chile.

\subsection{MATRIMONIOS CONCERTADOS}

Quizá la mayor muestra de que estamos frente a un mundo ya ido, sean los arreglos matrimoniales, donde los progenitores, en ocasiones los hermanos, o la casamentera, son quienes eligen al novio y/o novia. Sobre todo el padre aparece como el último juez del destino matrimonial de sus retoños. En Para siempre en mi memoria asistimos de manera recurrente a este tópico que forma parte de la cultura judía tradicional. La misma Gitl en Rusia terminó casada con Samuel por elección de sus hermanos.

Ya en la pensión, asistimos a un capítulo que es narrado como un cuento de hadas (burlesco) en versión judía. Una reescritura del viejo motivo de "la princesa y el dragón". La damisela es la enamorada Esther, y el malvado que la tiene secuestrada es su padre, el señor Markus. Esther lo mira "con el mismo gesto de la doncella prisionera de un monstruo" (Guralnik 2000: 86). Los jóvenes de la pensión, locos por la bella Esther, "se imaginaban que ellos algún día escalarían el castillo para salvar a la princesa de las garras del ogro" (Guralnik 2000: 86). Markus está dispuesto a entregar a su hija con una dote al príncipe, siempre y cuando el futuro marido sea lo que él considera un profesional de fuste (médico, ingeniero o abogado), y no lo que ve como "una profesión de mierda. ¡Farmacéutico!" (Guralnik 2000: 90). Hay una casamentera (yenta en yiddish), la señora Feigue, y un hada madrina que intercede y ayuda a salvar la situación: Gitl. Al final hay acuerdo, la yenta ha hecho su negocio, y todo apunta a una crítica de Guralnik a la costumbre ancestral de los matrimonios concertados. Qué mejor ironía que decirlo bajo el modelo de un cuento de hadas.

Esta tradición judía llegará a su fin con la historia de los primos Reizel y Leo. Ahora es la dulce mujer viuda quien viaja a Chile desde algún de Europa del Este a

\footnotetext{
5 Nos referimos al hecho de que se trata de una serie de relatos de múltiples personajes que arriban y habitan en la pensión, en un texto que está construido en torno a una trama cuyo hilo conductor es la vida de Gitl. No se trata propiamente de relatos enmarcados (al estilo del Quijote o Hijo de ladrón), pues en los episodios intervienen más o menos activamente Gitl, Samuel (su esposo), la Minduca (la sirvienta) y el coro de residentes de la residencial de calle Echeverría.
} 
encontrarse con el contador lisiado (quien tuvo una niñez traumática) que ha conquistado a Reizel. Ahora se "Celebraba la muerte del sufrimiento del hombre enamorado y el nacimiento de un amor seguro" (Guralnik 2000: 142). Todo esto puede parecernos un tanto de novela rosa; sin embargo, simboliza el fin de las bodas arregladas.

\subsection{EL CUESTIONAMIENTO DEL PRINCIPIO DE AUTORIDAD}

Acaso lo que más esté en juego en la novela es el modo de ejercer el principio de autoridad. Existe una complicidad comunitaria en la voz que recibimos: son historias amonedadas por el humor, desde las variantes del ridículo, el absurdo o el sinsentido. El sentimiento de rechazo hacia una Ley demasiado severa e inmisericorde aparece representado en el siguiente entremés: Gitl, con ciertos indicios de menopausia, provoca en la sobremesa al serio y adusto rabino Osías Piltnik, frotándolo contra su cuerpo. Este hombre invulnerable, gran predicador contra la lascivia, se queda en posición firme, lívido, con las manos arriba. Justo en ese momento, se escucha una "débil tosesita" (Guralnik 2000: 27), la del marido Samuel, irrumpiendo en el comedor. Los hechos se precipitan. El humilde Samuel, considerado por todos como "el trapero de la señora Gitl" (Guralnik 2000: 29), cuya actividad es la de "semanero a crédito" (Guralnik 2000: 29), le comunica a Osías que debe abandonar la pensión (lo cual implica abandonar el país). Cual Nuevo Moisés, éste organiza a la comunidad, la que le financia el viaje de vuelta a Rusia al terrible y latoso rabino. Así este esposo, a quien Gitl le recuerda diariamente que está dedicado a las Marías (las empleadasclientes chilenas), escolta al terrible Osías al puerto de Valparaíso desde donde éste regresa al mapa antiguo. De vuelta, la plebe inquiere detalles al héroe: "[...] que si había dado las gracias por los pasajes" (Guralnik 2000: 30); que cuáles habían sido sus últimas palabras; "Que si gritó de nuevo que este país era Sodoma y Gomorra" (Guralnik 2000: 30), como efectivamente lo hizo.

Este cuadro recién descrito, que aparece en los inicios de la novela, encuentra su complemento en otro dispuesto hacia el final: la llegada de Moshe Baraban, un joven tartamudo que se gana la vida tocando la katerinc $a^{6}$ y repartiendo pelotitas de aserrín, con un loro en su hombro. Este hombre tímido, que viste pantalones flotantes de payaso, es, en realidad, un profesor de religión y casi un rabino (salió mal en el último examen, por lo cual su mujer lo echó de la casa). Al melodioso y nostálgico son de su instrumento, este dulce personaje enseñará la Ley a los niños judíos de la pensión.

Así, al cierre de estos pequeños cuentos, celebramos paródicamente la venida de un nuevo orden.

\subsection{EL ESPACIO CHILENO: LA MINDUCA Y LOS HEROES JUDIOS SACRIFICADOS}

Hay un golpe rotundo, de pobreza solidaria chilena, que irrumpe con claridad en ese espacio: es la Minduca, lavandera y empleada, ascendida por la nutriente Gitl a ama de llaves. Será el contrapunto práctico de la dueña de la pensión, tan llena de remilgos nostálgicos. La Minduca representa la sabiduría popular en ese hábitat de personajes descolocados, a quienes llama "gringos". El momento cúlmine de su

\footnotetext{
${ }^{6}$ Instrumento ruso que se asemeja a un organillo.
} 
aguda visión se da frente a la historia de la polaca Genia Kislanov. "Agitando las pestañas", se llama el episodio donde se relatan las correrías de esta arribista mujer de voz ronca ("con arrestos de primadona" (Guralnik 2000: 54), a quien le gusta el baile, la champagne, los bares, y los vestidos provocadores, que se quedó esperando un novio en Varsovia antes de venirse a Chile. Genia cuenta que huyó de la revolución y que debió vender sus joyas para sobrevivir. La Minduca desconfía, mientras Samuel es de otra opinión: es una pobre mujer sola, y le cree que enviudó en la guerra. Por eso la Minduca se enfurece cuando Gitl arregla la boda con el viudo, practicante y acomodado don Leib. El desastre en que termina este matrimonio (desde el inicio, fue "una guerra sin cuartel" (Guralnik 2000: 58)) habrá de darle la razón a la Minduca. Nunca sabemos si por crueldad y/o sencillamente porque jamás fue judía (probablemente esta es la intención de Guralnik), Genia provoca a don Leib, encendiéndole velas a la Virgen de Lourdes en la pieza matrimonial. La polaca debe abandonar la residencial y la sirvienta celebra: "Esa tarde, cantando la Minduca comenzó a limpiar los cubiertos para Pesaj7" (Guralnik 2000: 61). La paz se ha restablecido y retorna el orden de las familias.

Y lo nacional se cuela también a veces por las rendijas. Norma Blum es una joven judía del barrio, comunista, que golpea la puerta para pedir refugio ante la persecución en los años de la llamada Ley Maldita de 1947. Quiere seguir escapando a otro lugar, pero es abatida por las balas en los techos de la casa. Asimismo, el denominado guerrillero Simón Garnitz, el hombrecito que vende el diario El Siglo en un carretón, es un mudito alegre, un allegado dispuesto por la misericordia rusa en la pieza de los cachivaches. Simón, quien para Gitl es sólo un hombre bueno, también será asesinado y despedido por sus compañeros al son de La Internacional. Norma y Simón serán así la rebelde y el guerrillero sacrificados por la violencia política que viene a alterar este estacionario lugar de inmigrantes.

Aunque la pensión sea un refugio de las persecuciones sufridas en el Viejo Mundo (los progroms, la revolución rusa de 1917 y la II Guerra Mundial), paradójicamente funciona también, a pesar de estos episodios, como una borradura en relación al espacio chileno que lo contiene. La residencial es una matriz sin futuro.

\subsection{LAS SOMBRAS DEL HOLOCAUSTO}

Hay una historia ambigua, "El señor Kantor", la de un alemán que tiene una vida doble. Llega a la residencial aduciendo que es un perseguido de guerra, y comparte pieza con Marcos Fisher. Kantor no recibe cartas ni visitas. Habla en sueños, ve gente desfilando: "-Se cree un torturador, un simulador, un especialista en el disfraz” (Guralnik 2000: 95). Luego comienza a desaparecer de la pensión y arrienda otro espacio, donde hay una foto de Hitler y la bandera nacionalsocialista. Kantor le rinde homenaje al líder, alza el brazo al estilo nazi. Posee una pistola Lüger, estuches de piel humana de donde extrae condecoraciones y Mein Kampf. Y dice en solitario: “-Pensé que iba enloquecer en esa pensión con el olor a perro judío. Jamás buscarán a un antiguo SS condecorado en ese lugar" (Guralnik 2000: 98). Se pierde su huella hasta que lo encuentran muerto en su nueva habitación. A pesar de preguntarse de

${ }^{7}$ Festividad religiosa que celebra la salida de los judíos de Egipto. 
dónde sacó el occiso la distinción de honor, Fisher piensa que Kantor ha enloquecido y que debe ser enterrado "como la ley mosaica lo ordena" (Guralnik 2000: 99). Gitl prohíbe hablar del tema, y opina que los hombres deben asistir a los funerales. Pero la gente se divide, los Rosen se excusan.

La historia de Kantor es un episodio donde pasa a segundo plano saber realmente quién es. Cualquiera sea la verdad de los hechos, el sentido último de este capítulo parece ser mostrarnos las miserias del Holocausto. ¿Era Kantor un judío que llegó a identificarse con sus opresores?; o ¿un kapo que colaboró con los nazis y perdió el juicio? ¿O simplemente un ex SS? Que sea un enajenado producto de su paso por los campos de concentración o un impostor fanático de Hitler son respuestas posibles, aunque la forma en que está construido el relato indica que fue un torturador de la SS.

La memoria judía dañada aparece con nitidez en este episodio amargo que hace de trágico contrapunto (al igual que las historias de Norma y Simón) con el acento humorístico y paródico que domina en Para siempre en mi memoria.

\section{Un Viaje ENTRE dos vacíos. Cynthia Rimsky}

Cynthia Rimsky es la protagonista y autora-narradora de Poste Restante ${ }^{8}$. En este texto, la heroína encuentra en el mercado persa de Avenida Arrieta un álbum de familia donde en su primera página se lee: "Plitvice in Jezersko/Rimski Vrelec/ Bled" (Rimsky 2001: 9). Se trata de fotos de vacaciones familiares que podrían ser los ancestros de la protagonista, cuyos orígenes por el lado paterno se encontrarían en un pueblo denominado Ulanov ("ubicado en algún lugar entre Moldavia, Polonia y Ucrania" (Rimsky 2001: 10), de donde vino el abuelo), y Cracovia, Polonia (la tierra natal de esta abuela, quien se trasladó luego a Varsovia). Los abuelos de la heroína arribaron a Chile en las primeras décadas del siglo XX.

Observando el índice-itinerario y la progresión del texto se trata de un viaje de salida y vuelta a Chile, donde cada capítulo se refiere a un lugar de visita, y en numerosos de ellos se incluye una viñeta llamada “Álbum de familia”. La travesía circular se prolonga desde diciembre de 1998 hasta septiembre de 1999, pasando por Londres, Israel, Egipto, Chipre, Rodas, Turquía, Ucrania, Polonia, Austria y Eslovenia.

Cada capítulo incluye varias viñetas, además de algunos artefactos. Refiriéndose a su texto, señala la autora que estamos frente a "crónicas de viaje, un poco a lo Walter Benjamin, un poco a lo Truman Capote: reflexiones desde un punto de vista personal. En Chile nadie se interesó por publicar estas viñetas tituladas Poste Restante..." (Rimsky 2001: 159). Los modelos literarios son decidores: un pensador judío y un periodista-escritor a quien se le atribuye la creación de la novela de no ficción.

\footnotetext{
8 Nació en Santiago en 1962. Estudió Periodismo en la Universidad de Chile, profesión que ha cruzado con la literatura. Antes de Poste Restante (segundo lugar en el Premio Municipal de Novela, 2002) publicó El aliento de Fátima (relato inédito que obtuvo el Primer Lugar de los Juegos Literarios Gabriela Mistral, 1995). En 2004 publicó La novela de otro.
} 


\subsection{INSTALACIONES}

Rimsky opera como una artista plástica, siendo su libro una real Instalación. Más que la información o la anécdota, importan aquí sus soportes: un cuaderno; una agenda; un computador; un álbum de 11,5 por $9 \mathrm{~cm}$ con fotos de 6 por $8,5 \mathrm{~cm}$; fotos de cajón (en fotocopias); y todo tipo de mapas: del metro de Londres; de Chipre (comprado en Limassol); de Ucrania; uno recortado de un periódico de Cracovia; mapas a mano con flechas; cruces y nombres (en hoja cuadriculada); cartas; postales y sus respectivos sobres; una carta al editor de una revista chilena (fotocopiada en reducción); un correo electrónico y, de paso, esquemas de posibles relatos literarios.

Existe un afán coleccionista en esta Instalación. Al inicio de la travesía se hace un inventario de ropa, dinero y objetos, además de que sabemos que existe un diseño de los puntos a visitar. Hay cierta compulsión de poseer a través de la constatación de marcas materiales. La señal del papel arrugado marcada en la fotocopia, las letras cursivas, el alfabeto cirílico, la misma distribución de los párrafos en la página. Es como si estos detalles (los bordes de las fotos cortados con tijera zigzag, la cinta que cuelga de la agenda), fueran capaces de regenerar una huella antigua (a pesar de no ser traducibles), a modo de sedimentos de la memoria.

Esta Instalación móvil funciona desde la decepción, el desplazamiento y la comunicación bloqueada. No vemos las fotos del álbum, sino que leemos su descripción; conocemos sólo cartas respondidas o sólo cartas enviadas (pero no el circuito total); leemos resúmenes de cuentos (los cuales no se escribieron o más bien los resúmenes los agotaron). Siempre algo se nos hurta, ése es el goce de la viajera, que se escapa entre estos resquicios, sin poder ser abordada plenamente. ¿Habrá aquí una resistencia a los grandes discursos que justifican nuestras vidas? ¿No es éste un pequeño objeto escrito en las antípodas del Talmud? ¿Podría citarse a Jameson, a propósito del sujeto postmoderno y plantear que aquí la alienación del sujeto ha sido sustituida por su fragmentación?

Alguien que llega justo antes o después a un lugar (de paso) donde supuestamente le espera una carta amiga (Poste Restante: cartas que son reclamadas en el correo de la respectiva ciudad: se sabe sólo el radio de acción del destinatario, pero no su punto exacto de residencia). Cartas que son devueltas a su remitente por no haber coincidido con el tiempo de la destinataria, misivas cual cuerpos errantes que miman el acto fallido de encontrar una casa, que juegan a hacerla aparecer y desaparecer, ficciones de la comunicación, simulaciones del acto del náufrago que lanza un mensaje dentro de una botella. Jugar a las despedidas y desencuentros, escenificar la ansiedad, actuar los saltos mortales del trapecio.

\subsection{PARADOJA Y CARTOGRAFIA DE LOS LIMITES}

Una paradoja de este libro lo constituye el hecho que Cynthia conoce parte de la historia de sus orígenes, que en varias instancias es como si fuesen un enigma. El viaje a Ulanov y Polonia sería una vuelta a la matriz, pero en verdad es más bien una confirmación de que pertenece a una familia judía emigrante a Chile que pareciera haber decidido anular su genealogía o, dicho de otro modo, renunciar a una filiación ancestral. El padre dentista, Teodoro, decide no viajar a Israel (sus hijos se lo habían ofrecido como regalo cuando llegaran a ser profesionales). La madre pasea en un 
crucero por el Caribe, y en vez de preguntarle en una carta a su hija en viaje qué le significa, qué siente de su búsqueda o qué ha encontrado, se dedica a describirle su aventura vacacional.

Y la propia protagonista sabe que en verdad no busca demasiado en Ulianov, que sólo es parte de un periplo (se llama a sí misma "una turista chilena"; "la viajera"; "una viajera chilena"; "la periodista"; "periodista chilena"; "la chilena"; "la mochilera"; "la huésped"; "una judía"). Los lugares visitados conforman diversas redes semánticas. Son, en primer lugar, cuerpos desplazados de una matriz original o que aparecen descalzados y que proponen el problema de los límites. La viajera se desplaza hacia la frontera de Israel y Egipto y luego se instala en Chipre, dividida artificialmente en dos (ella está en el Sur, donde hay dos bases inglesas). Nadie en Chipre está en su lugar. Las traslaciones chipriotas se analogan con las sustituciones en tierras de Polonia. Aquí la población original aparece ocupada (invadida) por fuerzas militares extranjeras y por el idioma inglés. En todos estos espacios ocurre un juego de identidades sexuales trocadas, como si en estos espacios de deslinde y de crisis aparecieran desenmascarados los tabúes. Finalmente, aparecen los espacios vaciados, borrados o desocupados, como las aldeas judías de Cracovia.

Cynthia se halla además desencontrada en su país natal, un espacio sofocante y donde carece de trabajo. Es una heredera del Chile postdictatorial, una desencantada de la transición a la democracia, alguien que parece sentir que no pertenece a ningún sitio, ¿o es que prefiere, como judía finisecular, verse a sí misma como simple ciudadana de la aldea global?

\subsection{JUDAISMO DE LA PROTAGONISTA}

La relación de Cynthia con sus raíces es de suyo ambigua. Es una hebrea que odia el Estadio Israelita en Santiago, y cuyo nombre no está en el registro computacional de la colonia chilena. Sin embargo, de niña asistía a la sinagoga en Santiago, y sabe cocinar comida judía.

¿Qué ve Cynthia, entonces, en el judaísmo? En la carta de Rita Ferrer parece estar su respuesta. Se trata de la ética hebrea: honestidad, estilo de vida, verdad. Y Rita agrega de su parte: "(parece que somos los únicos que se desvelan por seguir pensando en estas cosas, que parecen 'superadas' por el resto de la humanidad)" (Rimsky 2001: 43). Y Cynthia escucha con simpatía en Israel, aunque sin emitir juicio, a un judío religioso que afirma nada menos que los israelitas son los elegidos para ser la conciencia de la humanidad. Siendo honestos y actuando de acuerdo a la verdad, le dice el hombre, los demás tendrán a quien mirar; mientras se den cuenta "seguiremos estudiando la Torá" (Rimsky 2001: 40).

Luego de terminado su peregrinaje, Cynthia ha corroborado que el álbum encontrado en el mercado persa nada tiene que ver con su genealogía, y que la búsqueda de los orígenes, iniciada en Santiago más de medio año atrás, es una mera ilusión. Más bien la corroboración de que el olvido de sus abuelos y padres de los orígenes judíos termina para la autora-narradora en un vacío de principio a fin. Sin embargo, lo que prueba el viaje es más que nada que esta joven mujer hija de inmigrantes tiene a Chile como origen y destino, conformando los demás puntos un espacio en blanco que no logra generar una trascendencia o un nuevo camino. Sólo está allí como tejido roto, el cual a lo más sirve como pantalla para exhibir la crisis de la teología, la política, la familia y el amor. En realidad, son los paisajes del desencanto. 
Ahora bien, hay diversas formas de querer y de buscar y de encontrar. El libro se cierra con una carta escrita en yiddish y luego traducida al hebreo y luego al español, de una mujer ucraniana que emigró a Israel y que buscaba parientes por el mundo. En este caso, ella le está escribiendo a un grupo familiar que nunca ha conocido y que vive en Chile. Así, un viaje artificial en busca de parientes artificiales le trae siniestramente a Cynthia una correspondencia de una pariente real. Es como si el ansia de pertenencia nunca muriera y que el arraigo (sea Ucrania, Israel o Chile) sólo existe en una constelación. El único consuelo pareciera ser esta carta final que cierra Poste Restante. De esta forma conocemos brevemente la historia desconocida para nuestra heroína del tronco materno. Y Cynthia parece dejarnos como texto de cierre un desmentido. El religioso de Kiev estaba equivocado: no es una impostora ni una judía que ha traicionado la Ley de su pueblo por no estar segura de su apellido materno. La identidad hebrea es menos frágil de lo que parecía. Libro de la diáspora.

Al final, el álbum de familia encontrado, anécdota que da la partida a Poste Restante, queda finalmente en Eslovenia, en manos de Mateja Kavcic, heredera de la posada vacacional de Jezersko. Y en Cracovia-Kazimierz la narradora nos dice: "contemplo mi trizadura que transporto como un hogar..." (Rimsky 2001: 174). En consecuencia, el nido de Cynthia, su árbol genealógico, no la contiene, sino que es algo móvil adosado a su cuerpo como si fuese una herida que el Chile de fin del milenio no ha hecho más que ahondar.

\section{La escritura como Patria. Andrea Jeftanovic}

Así como en Marjorie Agosín está la querencia de madre e hija, también aparece la hija guacha de mamá. Esto ocurre en la novela Escenario de guerra, escrita por la más joven de nuestra serie de escritoras, Andrea Jeftanovic ${ }^{9}$. Es la historia de la fragmentación familiar -separación matrimonial, medios hermanos, constantes cambios de casa, crisis económicas, actitudes esquizoides de los padres- contada desde una mirada infantil infartada en la adulta.

En esencia, lo que se hace en Escenario de guerra es poner en escena una tragedia familiar y de la humanidad en las últimas seis décadas del siglo XX. Hay en todo el texto un adentro (la niña, la joven, la mujer y su clan o su pareja), y un afuera (la guerra y su devastación, inscrita en los personajes y golpeándolos además a través de los periódicos y la televisión). Para los participantes en este drama, lo privado y lo público, son el envés y el revés de mundos en conflicto ${ }^{10}$. A través de Tamara, la

\footnotetext{
9 Nació en Santiago en 1970. Socióloga por la Universidad Católica de Chile y Doctora en Literatura por la Universidad de California, Berkeley, se ha desempeñado como académica en la Universidad Diego Portales; ha dirigido talleres de creación literaria; ha sido crítica de teatro y ha mostrado un particular interés por la intertextualidad entre literatura y otras artes. Escenario de guerra (su novela prima) recibió en 1999 el primer lugar en los Juegos Literarios Gabriela Mistral. En 2007 publicó la novela Geografía de la lengua.

${ }^{10}$ Consultada sobre sus temas, Jeftanovic ha dicho: "Creo que hay un interés por el cruce en la 'biografía" íntima y la 'biografía' universal. Me interesa la superposición, el cruce de las historias subjetivas con la historia universal (guerras, dictaduras, estructuras económicas, conflictos culturales), y cómo se resienten esos macroeventos en los cuerpos, en las emociones, en las relaciones de las personas". Shade, Eunice, "Somos provincianos, conservadores y misóginos", entrevista en http://impreso.elnuevodiario.com. ni/2007/06/11/cultural/49773.
} 
protagonista-escritora, vamos recorriendo los laberintos de una memoria dañada, sus silencios y, al mismo tiempo, la imposibilidad del olvido.

Cabe señalar que su autora es hija de un padre yugoslavo-serbio y de una madre judía cuyos ancestros nos remiten a Bulgaria. Estas huellas biográficas habrían despertado su interés especial por grandes temáticas que aparecen en la novela: las matanzas masivas y la violencia indiscriminada que acompañan a los conflictos bélicos ${ }^{11}$.

Escenario de guerra será el espacio donde la autora transforme en relato literario su preocupación por estos tópicos.

\subsection{ESCRITURA: METAFORAS BELICAS Y EL CUADERNO AZUL}

Si bien el título de la novela pudiese llevar a pensar que en ella hay una sola guerra (la literal y reactualizada, que han traumado al padre, que nos remite a Yugoslavia a mediados y fines del siglo XX), en la trama somos testigos de que Tamara se enfrenta en realidad a otras circunstancias de su vida que son metaforizadas con imágenes de un conflicto armado. A lo que la heroína alude en estas instancias es a las agresiones de que es víctima en el ámbito familiar, particularmente a las de su madre (al igual que su padre nunca se nos revela el nombre propio), y en su relación con su pareja. En consecuencia, el quiebre definitivo de Tamara con Franz se narra en los siguientes términos:

Algo zozobra dentro de mí. Lloro en medio de la invasión, se contrae el territorio bélico. Se extiende un imperio de márgenes confusos. Sé que en las mañanas venideras desearé que él amanezca hundido en mi desnudez. Los soldados se paran en la línea de fuego. Él se ha ido, no hay trinchera que me defienda de este ataque sorpresivo. Me ametrallan en el centro del corazón. Comprendo que estoy en medio de la penumbra de la soledad (Jeftanovic 2000: 121-122).

De esta forma, observamos que en el escenario en que se ha desplegado la novela de Jeftanovic asistimos al menos a cuatro guerras, dos literales (en el mismo espacio pero separadas por medio siglo) y dos metafóricas. Mientras la(s) guerra(s) en el "otro continente" (Jeftanovic 2000: 26) se desarrollan en el ámbito público, las segundas corresponden al ámbito privado, donde a los ojos de Tamara los enemigos son básicamente su madre y Franz. Mientras la guerra literal la daña y le duele por los efectos que tiene sobre su padre y por su sentido de humanidad, las guerras privadas de la heroína amplían el ámbito de sus heridas y de su soledad.

En medio de esta orfandad, la importancia de la escritura se destaca en el texto. En el Acto III del capítulo 7, llamado "Mis palabras son un grito en la hoja", Tamara anota: "A medida que escribo sobre mi vida dejo de formar parte de ella, creando otra existencia entre líneas" (Jeftanovic 2000: 161). Puede hacerse notar que esta mirada

\footnotetext{
11 Ha declarado la autora: "Soy de madre judía, me impresionó muchísimo y me acuerdo a los 6 años, uno siempre tiene en la casa libros de historia, qué sé yo, el ver la foto del holocausto. No importa que sea el holocausto judío, es cualquier genocidio, puede ser Vietnam, puede ser Iraq, puede ser el genocidio armenio. Es la imagen de lo que puede hacer el hombre con el hombre". Hernández Villalvazo, Sergio A., "Leyendo a Andrea Jeftanovic", http://www.tiempo-naranja.org/revista/spip.php?article35.
} 
de la escritura como un aullido no sólo nos remite a Allen Ginsberg, sino también a António Lobo Antunes ${ }^{12}$.

Así, la única salida para esta abandonada es la construcción de un espacio propio, la escritura, donde puede ensayar un nuevo guión para reparar los roles de la madre y el padre y, de paso, impedir la repetición de la historia individual y comunitaria, ligada a la constante pérdida (de vidas, de cosas).

El texto de Jeftanovic funciona como un psicodrama animado por una niñamujer que actúa ante nosotros una crisis familiar y de sentido. Ansias de parirse de nuevo, de recrear un escenario donde se tenga total posesión y control para dibujar un destino armónico. La escritura como patria, que intercambia la destrucción por la vida creativa, el erotismo letal por el amor de los padres, su marca judaica por una letra identitaria.

La reparación viene de su destino como escritora, donde diseña una escena en la cual camina con su padre a cuestas (la joven Atlas), y le sonríe a su madre, dejándola como un personaje secundario, revisando fotos que la ligan tímidamente a un pasado más fraterno. La hija, que siente su extranjería, crea su soporte en un libro, la escritura como fórmula de identidad y refugio: "Nunca supe si éramos de aquí o allá. Fundé mi patria en un cuaderno azul, donde no soy minoría" (Jeftanovic 2000: 30). Un gesto individual e irrepetible, una letra pequeña salvadora, un deseo de reunión familiar sin estridencias.

\subsection{MARCAS JUDIAS: LO DICHO Y LO VELADO}

En Escenario de guerra jamás aparecen los términos judío, hebreo o israelita. La marca judía es en ocasiones eludida en la enunciación del relato, como si la protagonista tuviera vergüenza ajena o lo quisiera mantener en secreto o sólo para cierto público.

Así, la palabra estrella -símbolo principal del judaísmo, el maguen David-es utilizada en una oportunidad, pero en el contexto de la frase en que está inserta admite también el sentido de hado o sino. Tamara dice refiriéndose a su terapeuta: "Si usted me alumbra, naceré con otra estrella" (Jeftanovic 2000: 80). ¿O Tamara nos está diciendo que dada la tragedia familiar que le ha tocado vivir, y si pudiese nacer de nuevo, hubiese preferido no ser hebrea?

Las marcas judías en el texto se encuentran principalmente en el capítulo 5 del Acto I. La narradora establece aquí una distinción entre su casa y la de sus vecinos. Mientras las primeras señales de la diferencia se pueden referir a cualquier inmigrante (otro idioma, se reza a otro Dios, celebración de otras fiestas, aromas más dulces, otros adornos), luego aparecen objetos que nos remiten a lo judío: vidrios de colores (los vitraux de Chagall), candelabros (la menorál ${ }^{13}$ ) y "una placa en el umbral de la puerta" (31) (la mezzuza $\left.{ }^{14}\right)$.

\footnotetext{
12 El escritor portugués ha declarado: "Las palabras traicionan, son escurridizas: yo quisiera darles carne y sangre, escribir como si mi vida fuera un grito y mis libros un comentario a ese grito", entrevista de prensa en La Tercera, 27/11/2006.

13 Candelabro de siete brazos, símbolo del Estado de Israel.

14 Pequeño pergamino con versos de la Torá, que se coloca en el marco de la puerta, en la entrada de los hogares judíos.
} 
Sin alusión explícita a lo judío, Tamara nos cuenta a continuación que es diciembre, y los niños del barrio salen a la calle con sus juguetes nuevos. Entonces la niña expresa la frustración de cualquier infante hebreo en Navidad: "Ellos preguntan por mis regalos, no sé qué decir. No tengo nada nuevo que mostrar" (Jeftanovic 2000: 31).

El sentimiento de ser una huérfana y de su diferencia es reduplicado por la marca silenciada de lo judío, que no es traspasado a las siguientes generaciones. Los progenitores de Tamara pretenden negarle su genealogía, mientras que la heroína, aunque le aterra la historia familiar, necesita saber de dónde vienen y quiénes son sus padres. Ante este silencio que tensiona la definición de su identidad, sus fuentes son los libros, la enciclopedia.

Y la muerte del padre da lugar a que Tamara lleve a cabo dos ritos fúnebres judíos. Al salir del hospital luego del accidente donde murió su padre, regresa a casa y cubre los espejos con sábanas (el sentido de este acto de duelo en la tradición hebrea es evitar dar curso a la vanidad de los deudos). Además, respeta la semana de la sibá o duelo mayor, inmediatamente posterior al entierro: "Estoy de regreso a la calle y a la rutina después de permanecer siete días encerrada despidiendo a papá" (Jeftanovic 2000: 161).

De esta forma lo judío se devela en clave para lectores hebreos, o bien solo para quienes no son israelitas pero conocen la tradición religiosa y la cultura del pueblo mosaico.

A modo de cierre, cabe señalar que Escenario de guerra deja tres grandes interrogantes. ¿Se vela en ocasiones lo judío para esquivar los prejuicios antisemitas (una forma de autocensura), o a la autoría la moviliza mayormente la intención de hablar por toda diferencia? ¿O bien es que el peso de la tradición hebrea, como en el caso de Ana Vásquez-Bronfman (Las jaulas invisibles) y Alejandro Jodorowsky (Donde mejor canta un pájaro), se la visualiza también como una jaula o un corsé?

Leyendo uno de los epígrafes de Escenario de guerra, la cita de Virginia Woolf, pareciera que Andrea Jeftanovic comparte con Vásquez-Bronfman y Jodorowsky la necesidad de afirmar sus raíces y, a la vez, liberarse de su carga. Dice Woolf: "No quiero quedar fijada, inmovilizada. [...] Nada he gastado de mi herencia. Estoy en los inicios" (Jeftanovic 2000: 9).

\section{Colofón COMParativo}

La memoria nostálgica de la patria perdida. La memoria traumática producto de las persecuciones en Europa del Este, el Holocausto, la II Guerra Mundial (y su actualización en los años 90 postcaída del Muro de Berlín), y un antisemitismo ubicuo y atemporal. Y la memoria como tejido roto (árbol genealógico silenciado), con ancestros que soslayan sus raíces. Estas son las tres formas en que nuestras escritoras nos presentan una visión de lo que significa la pertenencia al pueblo hebreo. Se trata de voces femeninas (la abuela, la madre, la hija) que surgen dispuestas como muñecas rusas, exhiben la sobrevivencia de la voz judaica en el tiempo histórico y su inscripción en un tiempo sagrado.

La señora Gitl en Para siempre en mi memoria habita veinte años un barrio histórico de Santiago mirando hacia su Rusia original (recordando imágenes y objetos), encerrada y liderando un gueto de judíos pobres y tristes. Un espacio que se comunica apenas con el entorno nacional. Guralnik parece saber que ese gueto está condenado a la extinción, y libera hacia al final de la novela a su heroína, sacándola 
del enclaustramiento. Gitl desecha el viaje al origen y prefiere trabajar junto a Samuel. La memoria nostálgica se resuelve al fin con un nuevo comienzo: la integración a la patria chilena. Pero también conlleva hechos trágicos: los judíos huyendo de los progroms, la revolución bolchevique y el genocidio nazi. La residencial-gueto será el espacio temporal de protección donde se podrá, de manera precaria, mantener una identidad judía colectiva rodeada de un entorno que deja vivir sin amenazas.

A través de Agosín escuchamos una voz comunitaria, la escritora hablando por los suyos, por los hebreos chilenos y los judíos errantes de ayer y de siempre. Aun cuando para la familia Agosín no hay país de acogida, y a Chile se lo visualiza hostil aun hoy para los judíos, será junto a la identidad hebrea el único imaginario sólido, por la simple razón de que constituye el origen al cual todo ser nómada desea (necesita) retornar.

En Guralnik y Agosín el sujeto popular chileno ingresará a través de las empleadas domésticas (la Minduca y la Carmencita, respectivamente), pero construidas como figuras subalternas, objetos recipientes más que sujetos que disputen un espacio cultural y subjetivo en estas historias.

En Poste Restante el nido es una herida que se lleva inscrita en el cuerpo y que se curaría apelando a la ancestral práctica hebrea de la escritura. Pero no será al estilo de un texto tradicional, sino con una Instalación literaria, un libro neovanguardista escrito en las antípodas de la Ley hebraica, aunque colmado de normas (las importantes y numerosas marcas estético-formales del texto). La viajera será una mujer judía y periodista chilena cesante que, a diferencia de los protagonistas de Guralnik y Agosín, quienes se refugian en la identidad, comunidad y/o su familia judía, aparece antes nuestros ojos como un ser más centrado en sí mismo. La identidad judía la vivirá también como un foco de tensión, con acercamientos y deslindes, con una mirada crítica y cercana a la vez, instalada como una gran pregunta aún por resolver, matizada por el mestizaje cultural, en un Chile postdictadura que le niega a la heroína un espacio de acogida. Pero aun así, es su tierra, real y no labrada desde la nostalgia y el dolor como en el caso de Agosín.

Al igual que la protagonista de Poste Restante, lo que destaca de Tamara en Escenario de guerra es que privilegia su ser individual, la de una mujer solitaria; parece hallarse ajena de cualquier comunidad (judía o chilena), y su espacio identitario será la escritura, su cuaderno azul. Sólo a través de la letra Tamara resolverá el saberse parte de una minoría y una diferencia, y se protegerá de esta forma de la tragedia familiar y universal que marcaron su vida desde la niñez. Al igual que en Agosín, pero desde una perspectiva personal, la escritura para Tamara será el expediente para curar una memoria herida, el daño que la marcó en tanto ciudadana judía y de la humanidad. El destino de Tamara es un libro abierto: podría ser su país natal o el "otro continente". Y en el intertanto, la palabra, la literatura -inferimos- como su grito para nacer de nuevo, para fundirse en el cruce judío-chileno y/o afirmar su individualidad en la aldea global.

Las escritoras menores de la serie, Rimsky y Jeftanovic, habitantes del Chile de la dictadura y de la transición, comparten el malestar generacional de los más jóvenes con la cultura y la política. Acaso por ello, el único territorio no minado sea el del arte: la escritura como patria. En este caso, la memoria judaica no está adscrita necesariamente a un pueblo, sino a una memoria actual de un mundo globalizado donde se han perdido los referentes utópicos. 
A la errancia y el gueto de Agosín y Guralnik, se agregan en los casos de Rimsky y Jeftanovic los viajes circulares por cartografías esfumadas, cuyo punto de inicio y fin es el lugar donde se nació: Chile. Errancia programada, que juega con los descalces de la cultura, la religión y el género (en Rimsky); y gueto mental, la vivencia psíquica de una repetición no querida, rota por fugas y puesta entre paréntesis por un ejercicio literario cuyo modelo es el psicodrama (en Jeftanovic), para desprogramar la fatalidad familiar, reactuando roles y circunstancias.

Al comparar estas vivencias, notamos dos gestos muy distintos. Las voces de las escritoras mayores (Guralnik y Agosín, que por edad podrían ser abuela y madre) proyectan una identidad judaica prístina, desde la celebración de sus ritos y costumbres. Por contraste, las voces femeninas más jóvenes (Rimsky podría ser como una prima menor de Agosín, y Jeftanovic cercana a una hija) proyectan una identidad en tensión, más tocada por una sociedad global definida por la individualidad, el fragmentarismo y la itinerancia. Voces judías que guardan otras voces; voces personales cuyo sentimiento de otredad es colmado en un ejercicio obsesivo: una escritura edípica, que las llevará a descubrir los tabúes familiares, religiosos y culturales.

\section{OBRAS CITADAS}

Agosín, Marjorie. 1994. Sagrada memoria. Santiago de Chile: Editorial Cuarto Propio.

_ 1998. Always from Somewhere Else: A Memoir of my Chilean Jewish Father. New York: The Feminist Press, The City University of New York.

Guralnik, Sonia. 2000. Para siempre en mi memoria. Santiago de Chile: Ediciones B.

Hernández Villalvazo, Sergio A. "Leyendo a Andrea Jeftanovic". http://www.tiempo-naranja. org/revista/spip.php?article35.

Horan, Elizabeth R. 1992. "Emigrant Memory: Jewish Women Writers in Chile and Uruguay", en Passion, Memory, Identity, Marjorie Agosín (ed.). Albuquerque: University of New Mexico Press, pp. 117-160.

Jeftanovic, Andrea. 2000. Escenario de guerra. Santiago de Chile: Alfaguara.

Jodorowsky, Alejandro. 2005. Donde mejor canta un pájaro. Santiago de Chile: Random House Mandadori S. A.

Rimsky, Cynthia. 2001. Poste Restante. Santiago de Chile: Editorial Sudamericana, Biblioteca Transversal/Dos.

Shade, Eunice. 2007. "Somos provincianos, conservadores y misóginos". Entrevista a Andrea Jeftanovic. http://impreso.elnuevodiario.com.ni/2007/03/08/cultural/49773.

Vásquez-Bronfman, Ana. 2002. Las jaulas invisibles. Santiago de Chile: LOM Ediciones.

Waldman, Gilda. 2004. "La memoria, el viaje y la nueva identidad judía en América Latina: Estudio de un caso literario". Anales de la Literatura Chilena 5, pp. 221-225. 
